\title{
ECOLOGICAL IMPACTS OF USING CONTAMINATED FOOD IN THE BOTTOM TRAPS AND BARRIERS OF FISHES
}

\author{
Alaa A. Alne-na-ei ' and Mohamed T. Shaaban ' \\ 1. Zoology Department, Faculty of Science, Al-Menutiya \\ University, Shebeen Alkoom \\ 2. Botany Department, Faculty of Science, Al-Menufiya \\ University, Shebeen Alkoom
}

Key words: ecology, skin ulcers. fin erosion, bacteria, fungi. Tilapia zillii.

\begin{abstract}
Come fishermen use contaminated food in the bottom traps and $O$ barriers in the Nile branches to attract fish. Microbiological investigations showed that such food is highly contaminated by bacteria and fungi. The identified genera of bacteria in food material, water and skin lesions were Aeromonas. Pseudomonas. Bacillus and Actinomycetes. On the other hand. four species of fungi namely Aspergillus flavus, Aspergillus ierreus, Fusarium sp. and Penicillium chrysogenum were isolated from the contaminated food. The field observations revealed that Tilapia zillii samples collected from the area contaminated by such food had higher ratio of skin diseases compared to other sites. The skin diseases in this site included skin ulcer $(13.8 \%)$, fin erosion $(16.9 \%)$ as well as $t .1$. ions (10\%). The ratios of the skin ulcers $(>15 \%)$ and fin erosion $(>30 \%)$ of the total body area among male and female $T$. zillii from the contaminated site were elevated compared to other ratios. The seasonal variation of different skin diseases revealed that the maximum prevalence, ranging between $40.8 \%$ and $24.2 \%$, were detected in summer and spring respectively. The GLM statistical analysis revealed that site and season had significant effects $(p<0.05)$ on the frequency of skin diseases. There was insignificant correlation between the areas of minimal and moderate skin ulcers ( $<10 \%$ and $10-15 \%$ respectively) and fin erosions $(<15 \%$ and $15-30 \%)$ with the different biological variables of $T$. zillii males and females $\left(R^{2}\right.$ ranged between 0.01 and $0.22)$. However, the regression of severe skin ulcers $(>15 \%)$ versus such biological variables showed that feeding intensity (FI), fish condition ( $\mathrm{k}$ ) and hepato-somatic index (HIS) of males decreased
\end{abstract}


with increasing the area of skin ulcers, while TSI was not affected by this lesion. The trend was more obvious in case of females, where $\mathrm{Fl}$, $\mathrm{K}, \mathrm{HIS}$ and OSI were negatively affected by the skin ulcers. On the other hand, FI and $\mathrm{K}$ of males and FI, K and OSI of females were inversely correlated with severe fin erosions $(>30 \%)$. Laboratory investigations showed that the skin ulcers and fin erosions first appeared in the 5th day after the application of the contaminated food with or without water from site (B) in the aquaria. The mortality rate in fish, which were provided with the contaminated food with or without water from site (B), was $10 \%$ at day $18^{\text {th }}$ and $33.3 \%$ at days $19^{\text {th }}$ and $20^{\text {th }}$, reaching $100 \%$ at $22 n d$ day.

\section{INTRODUCTION}

The bottom traps and barriers are commonly used for fishing in the Nile tributaries. Traps are in the form of cages or baskets with different sizes and forms, and made with various materials such as wood, wicker, metal rods, and wire netting. The traps have one or more openings and are usually set on the bottom near shore. singly or in rows, connected by ropes. On the other hand, barriers are usually large nets in the form of circles or zigzag, fixed on stacks and are usually constructed in canals characterized by slow moving water. The fishermen are illegally using the contaminated food inside these traps and barriers, as baits, to attract fishes. Other fishermen scatter such food in water, one to three hours before using nets. The food particles are usually mixed with masses of mud to prevent moving with water current. The random preparation of such food is not based on scientific rules, where, the fishermen use dead chicken; chicken offal, decayed fleshy debris, animal blood and algae mixed with corn or wheat products. The contamination of such food may arise from the fermentation of food ingredients stored in plastic or metal vessels. This induces the activation of microorganisms such as bacteria, fungi and parasites. Most of fish diseases result from the poor food formulation and storage (Tacon, 1992). Such diseases might reduce productivity and overall ability of the ecosystem to maintain a population of fish that can be harvested (Noga, 2000).

There is increasing concern about changes occurring in the aquatic enviromments and about human activities that might be causing damage to these systems. The aim of the present study was to evaluate the relationship between the use of contaminated food and the appearance of ulcer disease and fin erosion among fishes caught 
by tarps and barriers in a Nile canal. Thus the study includes both field and laboratory investigations for assessing the ecological impact of such diseases on the biological status of fish.

\section{MATERIAL AND METHODS}

\section{Field sampling}

Specimens of Tilapia zillii were collected monthly in the period between March 2002 and February 2003 from 3 sites (A. B and C) on

Bahr Shebeen Canal (Fig. I). Site B was located at the area characterized by slow water current and excessive use of traps and barriers (Fig. 6). while sites $A$ and $C$ were located at three $\mathrm{km}$ up and down stream of the site B. respectively. A total of 320 fish were captured by fishermen from either site $A$ or $C$. using tranumel nets. while 640 fish were caught from site $B$ by the bottom traps and barriers. Other fish species that had the same symptoms of skin lesions were recorded.

\section{Pathological studies}

The fish were transported to the laboratory alive in oxygenated water. The fish were killed by blowing to the heads. Skin ulcers and fin erosions (epidermal loss) were described and evaluated according to Woo and Bruno (1999) and Noga (2000). Skin diseases vere categorized into three groups, based on their macroscopic appe: ace and their areas as the ratios of the total surface area of fissi. follows:

\section{a) Skin ulcers :}

1. Minimal skin ulcer $(<10 \%$ of total body area)

2. Moderate skin ulcer ( $10-15 \%$ of total body area)

3. Severe skin ulcer (>15\% of total body area)

b) Fin erosion :

4. Minimal fin erosion ( $<15 \%$ of total body area)

5. Moderate fin erosion ( $15-30 \%$ of total body area)

6. Severe fin erosion ( $>30 \%$ of total body area)

The areas of the skin ulcer and the total surface area of fish body were measured, using planimeter (LASICO, Los Angeles Scientific Instrument Co., INC.). To confirm the accuracy of planimeter method, fin erosions and skin ulcers were laid out on semi-transparent sheets and their outline traced; an estimate of the lesion surface area was then made by laying the outline on squared graph paper. Fin 
erosion was measured as fin area proportional to the total body area and averaged for caudal, dorsal, pectoral, ventral and pelvic fins. It was very important to take into consideration, the difference between normal skin ulcers or fin erosion and injuries caused by the friction of fish body with materials from which the traps are made. The total length $(\mathrm{cm})$, total body weight $(\mathrm{g})$ as well as weights $(\mathrm{g})$ of stomach, gonad and liver were estimated for each fish.

\section{Biological variables}

The biological variables for each fish were calculated according to the following equations:

1. Feeding intensity $\{\mathrm{Fl}=$ stomach weight $(\mathrm{g}) \times 100 /$ total fish weight $(\mathrm{g})\}$

2. Coefficient of body condition $\{\mathrm{K}=$ fish weight $(\mathrm{g}) \times 100 /$ total fish length $\left.{ }^{3}(\mathrm{~cm})\right\}$

3. Hepato-somatic index $\{$ (HIS $=$ liver weight $(\mathrm{g}) \times 100 /$ total fish weight $(\mathrm{g})$ )

4. Testicular-somatic index $\{$ CTSI $=$ testis weight $\times 100 /$ total fish weight $(\mathrm{g})$ \}

5. Ovarian-somatic index $\{$ (OSI $=$ ovary weight $\times 100 /$ total fish weight ( $g$ )

\section{Laboratory investigations}

During summer, other samples of Tilapia zillii (average weight $40.3 \pm 2.1 \mathrm{~g}$ and total Jength $11.3 \pm 1.2 \mathrm{~cm}$ ) were caught from a more or less unpolluted site, using trammel nets. Fish were transpored alive to the laboratory, in equipped glass aquaria $(40 \times 50 \times 60 \mathrm{~cm})$, containing dechlorinated tap water and continuously aerated by air pumps. The water criteria, which were maintained during the study, included dissolved oxygen $(7.9 \pm 0.4 \mathrm{mg} / \mathrm{l})$ and water temperature $\left(23.7 \pm 1.9^{\circ} \mathrm{C}\right)$. The fish were used in the following experiments.

\section{Experiment (1)}

Two glass aquaria, each containing ten fish, were used to evaluate the effect of contaminated food alone. Dechlorinated tap water was used in both aquaria. The fish of first aquarium were provided with normal food composed of fishmeal (control), while the fishes of the second aquarium were provided with the food materiais used by the fishermen. The fish of two groups were equally fed, once per day at 5 $\%$ of body weight. The fish from each aquarium were inspected daily 
to detect the frequency of skin ulcers and/or fin erosion. based on a similar method conducted in the field. The mortality rate for each aquarium was recorded.

\section{Experiment (2)}

Two other glass aquaria, each containing ten fish. were used to assess the simultaneous effect of water from site (B) and the food material used by fishermen Water from site (B) was used in both aquaria. The fish of first aquarium were provided with normal food composed of fish meal (control), while the fishes of the second aquarium were provided with the food material used by the fishermen. Fish of two groups were equally fed once per day at $5 \%$ of body weight. The ratios of skin ulcers and/or fin erosion as well as the mortality rate were observed. The bacteriological analyses of water and fish surface were carried out according to the method described below.

\section{Experiment (3)}

Three aquaria were additionally used to investigate the duration of infection; the first aquarium contained five normal fish and five fish infected by skin ulcers. The second and third aquaria contained five normal fish and five fish infected by either fin erosions or both of skin ulcer and fin erosion, respectively. The fish of three aquaria were provided with dechlorinated tap water and normal food composed of fishmeal once per day at $5 \%$ of body weight.

\section{Microbiological analyses}

Samples of the food used by fishermen, water and fish surfaces in experiment (2) were analyzed to investigate the presence of bacteria. The bacteriological investigation involved the identification and total viable bacterial counts of the identified bacteria found in the food material, water and skin lesions of experiment (1). Two $\mathrm{g}$ of food material were suspended in $20 \mathrm{ml} 0.09$ physiological saline solution in a conical flask; the flasks were then left in a shaker for $3 \mathrm{~h}$. A dilution series was then prepared and used to inoculate the nutritive growth plates. A known volume $(0.2 \mathrm{ml})$ of water or food suspension was then aseptically transferred to the surface of previously prepared sterile nutrient agar plates. They were then incubated at $30^{\circ} \mathrm{C}$. The media used were nutrient agar plates for total viable counts and Bacillus sp. counts. Citrimide agar plates were used for isolation and 
investigation of Aeromonas sp.; Pseudomonas sp. (King et al., 1954) and starch nitrate agar medium were applied for investigation and isolation of Actinomycetes (Waksman, 1961). Bacterial counts on skin lesions were investigated, using sterile cotton swabs that were rolled in the skin ulcer or fin erosion. The swabs were then suspended in sterile test tubes each containing $10 \mathrm{ml}$ sterile saline solution, shaked and diluted up to $10^{-4} \cdot 0.2 \mathrm{ml}$ of each sample was used to inoculate the bacterial growth plates of each of previously mentioned media for different bacterial investigations.

On the other hand, fungi were isolated and counted only in the food material used by the fishermen. The food-born saprophytic fungal species were isolated by transferring $1 \mathrm{~g}$ of food sample to a conical flask containing $100 \mathrm{ml}$ sterile distilled water. Aliquot $1 \mathrm{ml}$ sample was placed in 5 replicates sterile Petri dishes. Under aseptic conditions, about $15 \mathrm{ml}$ aliquot of sterilized Dox medium were poured in each dish and dispersed by gentle rotating. Afier solidification, the plates were then incubated at $27 \pm 1{ }^{\circ} \mathrm{C}$ for 7 days, after which the developed fungal colonies (CFU) were counted, purified, and identified

\section{Statistical analysis}

General linear model (GLM) that provides regression analysis and two-way multivariate ANOVA was applied to determine the effects of site and season on the distribution of skin ulcers and fin erosions. The regression analysis was performed to evaluate the relationships between the skin ulcers, as a proportion of total surface body area (independent variable), and FI. K, HIS, OSI and TSI (dependent variables). The fit line with highest coefficient of determination $\left(R^{2}\right)$ was used after the application of different models of regression analysis. The comparison between means and standard deviations of bacterial counts were tested for significance, using two independent samples $t$-test. Statistical procedures were carried out with SPSS software program (Version 11.1) All tests of significance were made at the $p<0.05$ level.

\section{RESULTS}

\section{(I) Field observations}

\section{A. Prevalence of skin diseases}

The population of Tilapia zillii (Fig. 2a) collected from site B had higher ratio of skin diseases (40.6\%) compared to site $A(6.9 \%)$ and site $B(10.0 \%)$. Skin diseases (Fig. 2 b) that were observed in site (B) 
included skin ulcer $(13.8 \%)$; tin erosion $(16.9 \%)$ as well as both lesions $(10 \%)$. In contrast, minimum ratios of corresponding diseases were observed in site $\mathrm{A}(2.5,3.8,0.6 \%$, respectively) and site $\mathrm{C}(3.1$. $4.4,2.5 \%$, respectively). On the other hand, the observed skin diseases were elevated among females $T$. zillii captured from site (B) than males (Fig. 3a). The ratios of the skin ulcers $(>15 \%)$ and fin erosion $(>30 \%)$ of the total body area of both male and female $T$. zillii from site (B) were elevated compared to other ratios (Fig. $3 b$ and $3 c$ ). The total seasonal variation of skin lesions (Fig. 4) revealed that. the maximum prevalence ranged between $40.8 \%$ and $24.2 \%$ was detected in summer and spring respectively. The trend was fluctuated during autumn and winter. The GLM statistical analysis revealed that. site and season had significant effects $(p<0.05)$ on the frequency of skin diseases (Table 1).

\section{B. Effect on biological parameters}

There was insignificant correlation between the areas of minimal and moderate skin ulcers $(<10 \%$ and $10-15 \%$, respectively) and fin erosions $(<15 \%$ and $15-30 \%)$ and different biological variables of males and females $T$. zillii $\left(R^{2}\right.$ ranged between 0.01 and 0.22$)$. However, the regression of severe skin ulcers $(>15 \%)$ versus such biological variables (Table 2) showed that. $\mathrm{Fl}, \mathrm{K}$ and HSI of males $T$. zillii decreased with increasing the area of skin ulcers, while TSI was not affected by this lesion. The trend was more obvious in case of females, where FI, K. HIS and OSI were negatively affected by the skin ulcers. On the other hand, FI and $\mathrm{K}$ of males and FI, K and OSI of females (Table 2) were inversely correlated with severe fin erosions (>30\%).

\section{(II) Laboratory investigations}

\section{A. Experiment (1)}

The skin ulcers and fin erosion first appeared in the 5th day after the application of the contaminated food only in experiment (1). The symptoms of both diseases were similar to those observed in the field (Fig. 7a). Skin ulcer was first recognized as a red pimple on the skin. up to $5 \mathrm{~mm}$ that quickly widened and transformed into a white ring of necrotic tissue and debris around the edge of the lesion, with a large outer zone of inflammation extending into healthy tissue. The scales surrounding the lesion were sloughed off in acute cases. At the tenth day, the ulcers became progressively bigger. The skin uicers ranged from whitish discoloration to shallow hemorrhagic ulcers to deep 
ulcers that may expose underlying muscles with blood bleeding (Fig. $7 \mathrm{~b})$. The ulcerative lesions demonstrated marked chronic inflammatory infiltrate in large areas of exposed necrotic muscle. It was noticed that, most of skin ulcers were found above heads. On the other hand, fin erosions started with a slight discoloration of the edges of the fins, often red and white in color. The fins became ragged and erosion progressed to involve the fin rays and then to the base of the fins. In particularly severe cases, erosion extended to the fish's body around the fin base (Fig. 7b). The caudal and anal fins were most frequently affected. However, the above mentioned diseases were not observed in the control fish.

\section{B. Experiment (2)}

The symptoms of skin ulcers and fin erosion were similar to those observed in experiment (1) and in the field. The skin lesions first appeared also on the 5th day as in experiment (1). However, the bacterial counts in water and fish surface in the aquarium that received both food material and water from site (B) were significantly $(p<0.05)$ higher than the control aquarium that contained only water from site (B). The identified genera of bacteria in both aquaria were Aeromonas, Pseudomonas, Bacillus and Actinomycetes, although the latter was not isolated from the fish surface of control aquarium (Table 3).

\section{Mortality}

No mortality occurred in the reference fish that were supplied with either normal diet (experiment 1) or water from site (B) (experiment 2). In contrast, the mortality rate in fish, which were provided with either contaminated food alone (experiment 1 ) or both contaminated food and water from site (B) (experiment 2), was $10 \%$ at day $18^{\text {th }}$ and $33.3 \%$ at days $19^{\text {th }}$ and $20^{11}$, reaching $100 \%$ at 22 nd day (Fig. 5).

\section{Duration of infection}

In experiment (3) skin ulcers and fin erosions first appeared after 10 and 7 days, respectively. On the other hand, fish suffering from both skin ulcers and fin erosions were first observed after 12 days.

\section{E. Microbiological analyses of food}

The microbiological investigation showed that the food material used by fishermen was highly contaminated. by bacteria and fungi. The identified genera of bacteria were Aeromonas, Pseudomonas, Bacillus and Actinomycetes (Table 3). On the other hand four species of fungi namely Aspergillus flavus, Aspergillus terreus, Fusarium sp. and Penicillium chrysogenum were isolated from the food material. 


\section{DISCUSSION}

The present results indicated that, the population of Tilapia zillii inhabiting the area of contaminated food had higher proportion of skin diseases compared to other areas. Bacteria and fungi detected in food materials are possibly the causative agents responsible for the appearance of the skin diseases. Since there was a significant effect of season on the frequency of skin diseases. theretore, an environmental factor such as water temperature may be implicated in the occurrence of these lesions. Consistent with the present observations, bacteria were reported as infectious pathogens that can cause skin diseases in fishes such as skin ulcer (Baya et al., 1990; McGarey et al., 1991; Singh and Sanyal, 1999 and Madetoja et al.. 2003) and fin lesion (Murchelano and Ziskowski, 1977 and Khain ef al., 1981). On the other hand, fungi (McKenzie and Hall. 1976 and Noga, 1993) have been shown to damage skin epithelium and play important role in skin ulcer pathogenesis. Lovell (1992) mentioned that, the fungal toxins or "mycotoxins" such as aflatoxins, vomitoxin and ochratoxin are produced by filamentous fungi belonging to the Aspergillus, Penicillium and Fusarium genera found in poor-formulated foodstuffs. Recent studies have shown that. skin damage not only occur via direct contact with toxins, but it may also be induced indirectly from physiological changes that result from exposure to other environmental stressors, such as water temperature (Noga. 2000), pH (Nowak, 1999) and oxygen depletion (Mellergaard and Nielsen. 1995). By this concern, it is important to clarify that, many bacteria in ulcerative mycosis lesions and organs of affected fish are potential human pathogens (Noga and Dykstra, 1986 and Mokhlasur et al., 2002).

Other than bacteria and fungi, the causes of skin ulcers reported in several studies are diverse, including the exposure of fish to viruses (Smail, 2000) and parasites (Noga, 1986), along with the acute confinement stress that caused skin ulceration on the fins of striped bass and hybrid bass (Noga, et al., 1998). In a recent study, skin ulcer epidemics have been either experimentally or epidemiologically linked to exposure to a number of xenobiotic chemicals as well as to biotoxins such as toxins produced by the dinoflagellate alga Pfiesteria (Noga, 2000). Concerning fin erosion, the contaminant sediments were involved in the etiology of fin erosion of demersal fishes (Sherwood and Mearns, 1978), the tissue analyses of fish with fin 
erosion indicated an association between DDT and polychlorinated biphenyl (PCB) levels and the presence of the disease. The study published by Cross (1985) provided evidence that the prevalence of the fin erosion declined with increasing distance from the waste discharge sites. The exposure of Oreochromis niloticus to $40 \%$ and $50 \%$ petroleum refinery effluent (Onwumere and Oladimeji, 1990) induced erosion of the caudal fin. Furthermore, Hopkins et al. (2003) reported an association between coal combustion wastes (ash) and severe skin erosion of the benthic fish Erimyzon sucetta.

In the present study, the frequency of skin diseases was significantly elevated among females than in the males. Similar result was achieved by Sharples et al. (1994) in the study of the prevalence of fin erosion in the goldfish (Carassius auratua) exposed to bleached kraft mill effluent. The interpretation of this observation is uncertain, but it may be linked with the sexual hormones. The evidence from the present study is that, the TSI of males $T$. zillii were not significantly affected either by skin ulcers or by fin erosion, while females showed decreased OSI with increasing lesion areas. In their study on Atlantic salmon, Mork ef al. (1989) indicated that male teleosts might show a relatively enhanced resistance to fin erosion as a consequence of sexlinked physiological differences. On the other hand, Fletcher (1981) assumed that skin damage in fish might be a function of the physical properties of the epidermis such as its thickness and abundance of mucus.

The regression analyses of the present data reveated that, the minimal and moderate skin lesions had no effects on the biological status of fish. Among fish with advanced lesions, however, the biological parameters such as FI, K, HIS and OSI were decreased with increasing the area of severe skin ulcers. On the other hand, FI and $\mathrm{K}$ of males and $\mathrm{Fl}, \mathrm{K}$ and OSI of females were inversely correlated with the severe fin erosions. Such adverse effect of skin diseases may be attributed to either increased energy costs from locomotion due to loss of mucus production and/or impairment of swimming performance due to fin erosion. Hopkins et al. (2003) emphasized that, swimning speed was approximately $50 \%$ lower in fish suffering from severe fin erosion, and the reduction in swimming function led to physiological disruptions and decreased body conditions. $57.6 \%$ of the female perch exposed to leachate, as indicated by Noaksson et al. (2003), were found to suffer from high frequencies of skin lesions, fin erosion, and decreased gonadosomatic index. Ventura and Grizzle (1988) suggested that, skin infections with 
Aeromonas hydrophila occurred in fish that had already reduced condition factors. Fish exposed to coal ash-polluted sediments exhibited substantial severe fin erosion and decreases in growth (Hopkins et al., 2000). On the other hand, the mortality of $T$. zillii in the present study reached $100 \%$ at 22 nd day after exposure to the contaminated food. Since. the observed ulcerations were associated with hemorrhage; thus mortality was probably due to physiological stress resulting from excessive blood loss through skin ulcers. There is evidence that, ulceration of as little as $10 \%$ of body surface area can result in very high (near $50 \%$ ) acute mortality, probably because of osmotic stress, and the degree of mortality is directly related to the amount of skin loss (Bouck and Smith. 1979). Atlantic salmon with skin lesions, as suggested by Kent et al. (1988) had significantly greater plasma sodium and died most likely of osmoregulatory failure. Couch and Fournie (1993) emphasized that the large numbers of microorganisms present in advanced ulcers combined with the osmotic stress caused by large ulcers contributed to the death of fish.

Generally, the use of contaminated food may affect the integrity of fish populations due to the abundance of pathogens among fishes and consequently increased susceptibility of diseased fish to predation. The inadequate formulation of the contaminated food using random quantities of animal debris, blood and vegetation, result in the release of harmful microorganisms during decomposition. Wong et al. (1982) reported that, animal manures and sewage sludge used as supplementary feeds for the common carp Cyprinus carpio were more toxic. They therefore suggested that, waste materials should be pretreated and detoxified before using in animal feeds. Awareness of fishermen in this concern is important via governmental and nongovernmental authorities, since the principal goal of fishermen is to collect fishes regardless of the way, legal or illegal. They catch fishes irrespective of the fish status, healthy or diseased, even they sell the skin-ulcerated and fin-eroded fishes for duck farms by low prices.

\section{ACKNOWLEDGMENTS}

The authors would like to thank Dr. Mohammed M. Gharieb, Assistant Prof. of Microbiology, Botany Department, Faculty of Science, Al-Menufiya University, for his valuable help in the analysis of food samples. 


\section{REFERENCES}

Baya, A. M. ; Lupiani, B. ; Hetrick, F. M. ; Roberson, BS. and Poukish, C. (1990). Association of Streptococcus sp. with fish mortalities in the Chesapeake Bay and its tributeries. J. Fish. Dis., 13: 251-253.

Bouck, G. R. and Smith, S. D. (1979). Mortality of experimentally descaled smolts of coho salmon (Oncorhynchus kitsutch) in fresh and salt water. Trans. Am. Fish Soc., 108: 67-69.

Couch, J. A. and Fournie, J. W. (1993). Pathology of Marine and Estuarine Organisms. U. S. Environmental Protection Agency. Office of Research and Development. Gulf Breeze, Florida. pp: 85-110.

Cross, J. N. (1985). Fin erosion among fishes collected near a Southern California municipal wastewater out-fall. Fish. Bull., 83: 195-206.

Fletcher, G. L. (1981). Non-antibody molecules and the defense mechanisms of fish. In: Stress and Fish (ed. By A.D. Pickering). Academic Press, London. pp: 171-179.

Hopkins, W. A. ; Snodgrass, J. W. ; Roe, J. H. and Jackson, B. P. (2000). Detrimental effects associated with trace element uptake in lake chubsuckers (Erimyzon sucetla) exposed to polluted sediments. Arch. Environ. Contam. Toxicol., 39(2): 193-199.

Hopkins, W. A. ; Snodgrass, J. W. ; Staub, B. P. ; Jackson, B. P. and Congdon, J. D. (2003). Altered swimming performance of a benthic fish (Erimyzon sucetta) exposed to contaminated sediments. Arch. Environ. Contam. Toxicol., ff(3): 383-389.

Kent, K. L. ; Dungan, C. F. ; Elston, R. A. and Holt. R. A. (1988). Cytophaga sp. (Cytophagales) infection in seawater penreared Atlantic salmon Salmo salar. Dis. Aquat. Org., 4: 173179. 
Khan, R. A. ; Campbell, J. and Lear, H. (1981). Mortality in captive Atlantic cod, Gadus morhua, associated with fin rot disease. J. Wildl. Dis., 17(4): 521-527.

King, E. O. ; Ward, M. K. and Raney, D. E. (1954). Two simple media for demonstration of pyocyanin and fluorescin. J. Lab. Clin. Med., 44: 301-307.

Lovell, R. T. (1992). Mycotoxins: hazardous to farmed fish. Feed International, 13 (3): 24-28.

Madetoja, J. ; Staffan, N. and Wiklund, T. (2003). Survival and virulence of Flavobacterium psychrophilum in water microcosms. Microb. Ecol., +3 (2): 217-223.

McGarey, D. J. ; Milanesi, L. Foley, D. P. ; Reyes B. J. and Lim, D. V. (1991). The role of motile aeromonads in the fish disease, ulcerative disease syndrome (UDS). Experientia Rev., 47: 44 1444.

McKenzie, R. A. and Hall, W. T. (1976). Dermal ulceration of mullet (Mugil cephalus). Aust. Vet. J., 52(5): 230-231.

Mellergaard, S. and Nielsen, E. (1995). Impact of oxygen deficiency on the disease status of common dab Limanda limanda. Dis. Aquat. Org., 22: 101-114.

Mokhlasur, R. ; Patricia, C. ; Külın. I. and Huys, G. (2002). Identification and Characterization of Pathogenic Aeromoness veronii Biovar Sobria Associated with Epizootic Ulcerative Syndrome in Fish in Bangladesh. Appl. Envir. Microbiol., 68(2): 650-655.

Mork, J. ; Jarvi, T. and Hansen, L. P. (1989). Lower prevalence of fin erosion in mature than in immature Atlantic salmon (Salmo salar) parr. Aquacult., 80:223-229.

Murchelano, R. A. and Ziskowski, J. (1977). Histopathology of an acute fin lesion in the summer fiounder, Paralichthys dentatus, and some speculations on the etiology of fin rot disease in the New York Bight. J. Wildl. Dis., 13(1): 103-106. 
Noaksson, E. ; Linderoth, M. ; Bosveld, A. T. ; Norrgren. L. and Balk L. (2003). Endocrine disruption in brook trout (Salvelinus. fontinalis) exposed to leachate from a public refuse dump. Sci. Total Environ., 305(1-3): 87-103.

Noga, E. J. (1986). The importance of Lernaea crmciata (LeSeuer) in the initiation of skin lesions in largmouth bass. Hicropterus salmoides (Lacepede) in the Chowan River, North Carolina. USA. J. Fish. Dis.. 9: 295-302.

Noga, E. J. (1993). Fungal diseases of freshwater fishes: Recent advances. Ann. Rev. Fish Dis.. 3: 291-304.

Noga, E. J. (2000). Skin ulcers in fish: Pfiesteria and other etiologies. Toxicol. Pathol., 28(6): 807-823.

Noga, E. J. and Dykstra. M. J. (1986). Oomycete fungi associated with ulcerative mycosis in Atlantic menhaden. J. Fish Dis.. 9: 4753.

Noga, E. J. ; Botts, S. ; Yang, M. S. and Avtalion. R. (1998). Acute stress causes skin uiceration in striped bass and hybrid bass (Morone). Vet. Pathol., 35(2):102-107.

Nowak, B. F. (1999). Significance of environmental factors in aetiology of skin diseases of teleost fish. Bull. Eur. Ass. Fish Pathol., 19(6): 290-293.

Onwumere, B. G. and Oladineji, A. A. (1990). Accumulation of metals and histopathology in Oreochromis niloficus exposed to treated NNPC Kaduna (Nigeria) petroleum refinery effluent. Ecotoxicol. Environ. Saf.. 19(2):123-134.

Sharples, A. D. ; Campin, D. N. and Evans, C. W. (1994). Fin erosion in a feral population of goldfish, Carassius auratus (L.), exposed to bleached kraft mill effluent. J. Fish Dis., 17: 483493.

Sherwood, M. J. ; Mearns, A. J. (1978). Environmental significance of fin erosion in southern California demersal fishes. Ann. Acad. Sci., 29(298): 177-189. 
Singh, D. V. and Sanyal, S. C. (1999). Virulence patterns of Aeromonas eucrenophila isolated from water and infected fish. J. Diarrhoeal. Dis. Res., 17(1): $37-42$.

Smail, D. A. (2000). Isolation and identification of Viral Haemorrhagic Septicaemia (VHS) viruses from cod Gadus morhua with the ulcers syndrome and from haddock Melanogrammus aeglefinus having skin haemorrhages in the North Sea. Dis. Aquat. Organ., 4l(3): 231-235.

Tacon, A. G. J. (1992). Nutritional fish pathology. Morphlogical sign of nutrient deficiency and toxicity in farmed fish. FAO Fish Technical Paper. No. 330. Rome, FAO. 75 pp.

Ventura, M. T. and Grizzle, M. J. (1988). Lesions associated with natural and experimental infections of Aeromonas hydrophila in channel catfish, Ictalurus punctatus (Rafinesque). J. Fish Dis., 11: 397-407.

Waksman, S. A. (1961). The Actinomycetes. Classification, Identification and Description of Genera and Species. Vol. II. Baltimore: Williams and Wilkins Co. 363pp.

Wong, M. H. ; Cheung. Y. H. and Lau, W. M. (1982). Toxic effects of animal manures and sewage sludge as supplementary feeds for the common carp Cyprinus carpio. Toxicol. Lett., 12(1): 65-73.

Woo, P. T. K. and Bruno, D. W. (1999). "Fish Diseases and Disorder. Viral. Bacterial and Fungal Infections", CAB Int. Publishing, New York. USA. 874 pp. 


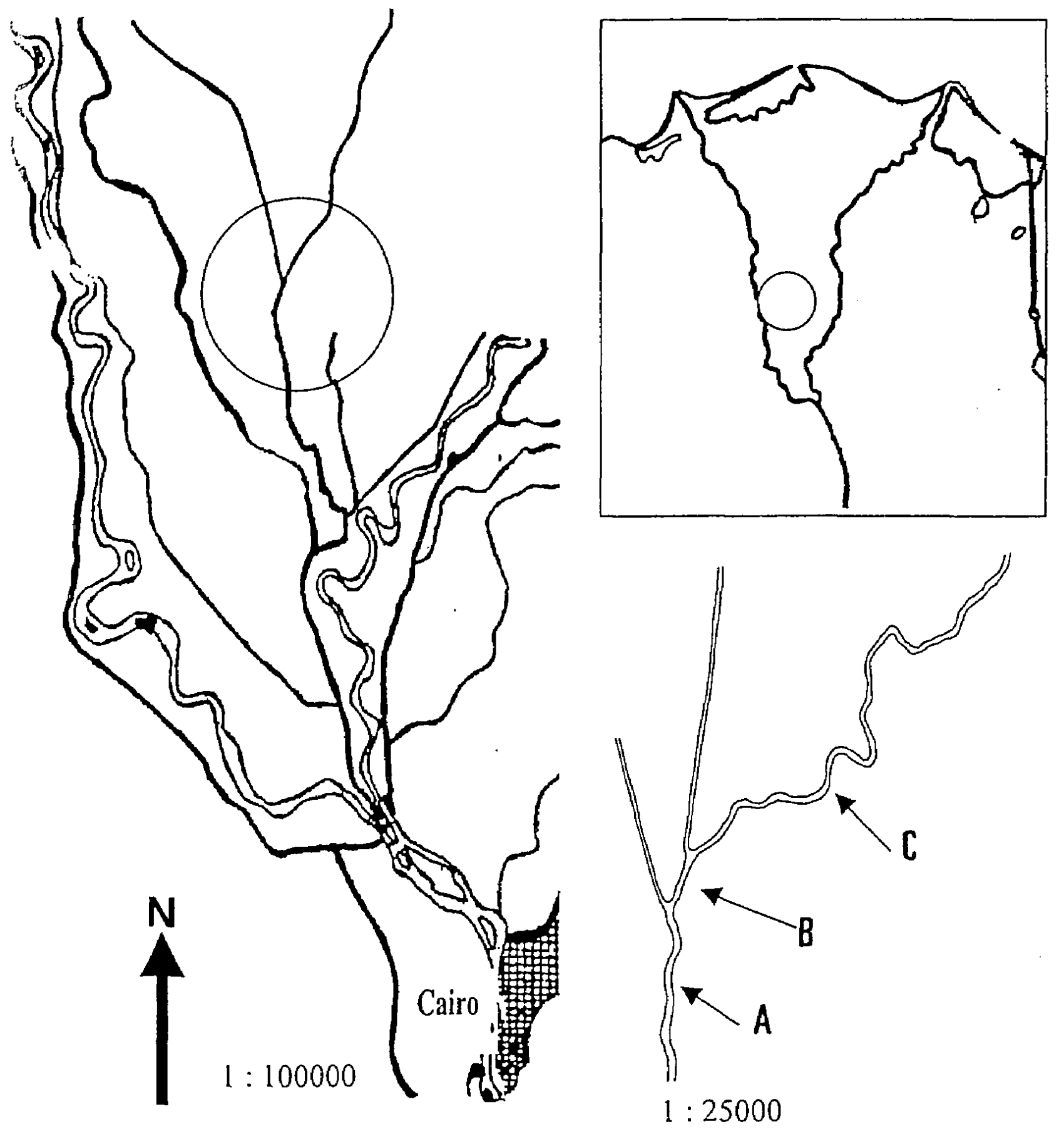

ig. (1 ). Map showing the area of study (Bahr Shebeen Canal). 
Table (1). The effects of season and site on the frequency of skin ulcers, fin erosions and both lesions of Tilapia zillii as determined by the general linear model (GLM) based on the two-way multivariate ANOVA analysis.

\begin{tabular}{|c|c|c|c|c|c|}
\hline Source & $\begin{array}{l}\text { Dependent } \\
\text { variables }\end{array}$ & $\begin{array}{l}\text { Type III } \\
\text { sum of } \\
\text { squares }\end{array}$ & $\begin{array}{c}\text { Mean } \\
\text { squares }\end{array}$ & F value & $p$ \\
\hline $\begin{array}{l}\text { Corrected } \\
\text { model }\end{array}$ & $\begin{array}{l}\text { Skin ulcer } \\
\text { Fin erosion } \\
\text { Both }\end{array}$ & $\begin{array}{l}175.58^{\mathrm{a}} \\
256.49^{\mathrm{b}} \\
119.93^{\mathrm{c}}\end{array}$ & $\begin{array}{l}58.48 \\
85.49 \\
39.98\end{array}$ & $\begin{array}{l}29.81 \\
28.94 \\
54.99\end{array}$ & $\begin{array}{l}0.001 \\
0.001 \\
0.001\end{array}$ \\
\hline Intercept & $\begin{array}{l}\text { Skin ulcer } \\
\text { Fin erosion } \\
\text { Both }\end{array}$ & $\begin{array}{l}11.68 \\
26.89 \\
7.35\end{array}$ & $\begin{array}{l}11.68 \\
26.89 \\
7.34\end{array}$ & $\begin{array}{l}5.95 \\
9.10 \\
10.11\end{array}$ & $\begin{array}{l}0.019 \\
0.004 \\
0.003\end{array}$ \\
\hline Season & $\begin{array}{l}\text { Skin ulcer } \\
\text { Fin erosion } \\
\text { Both }\end{array}$ & $\begin{array}{l}17.60 \\
18.70 \\
11.27\end{array}$ & $\begin{array}{l}17.60 \\
18.70 \\
11.27\end{array}$ & $\begin{array}{l}8.97 \\
6.33 \\
15.5\end{array}$ & $\begin{array}{l}0.004 \\
0.016 \\
0.001\end{array}$ \\
\hline Site & $\begin{array}{l}\text { Skin ulcer } \\
\text { Fin erosion } \\
\text { Both }\end{array}$ & $\begin{array}{l}157.88 \\
237.79 \\
108.67\end{array}$ & $\begin{array}{l}78.93 \\
118.98 \\
54.33\end{array}$ & $\begin{array}{l}40.23 \\
40.25 \\
74.75\end{array}$ & $\begin{array}{l}0.001 \\
0.001 \\
0.001\end{array}$ \\
\hline Error & $\begin{array}{l}\text { Skin ulcer } \\
\text { Fin erosion } \\
\text { Both }\end{array}$ & $\begin{array}{l}86.33 \\
129.98 \\
31.98\end{array}$ & $\begin{array}{l}1.96 \\
2.95 \\
0.73\end{array}$ & & \\
\hline Total & $\begin{array}{l}\text { Skin ulcer } \\
\text { Fin erosion } \\
\text { Both }\end{array}$ & $\begin{array}{l}577.0 \\
887.0 \\
352.0\end{array}$ & & & \\
\hline $\begin{array}{l}\text { Corrected } \\
\text { model }\end{array}$ & $\begin{array}{l}\text { Skin ulcer } \\
\text { Fin erosion } \\
\text { Both }\end{array}$ & $\begin{array}{l}261.81 \\
386.48 \\
151.92 \\
\end{array}$ & & & \\
\hline
\end{tabular}

a. $R$ squared $=0.670$ (Adjusted $R$ squared $=0.648$

b. $R$ squared $=0.664$ (Adjusted $R$ squared $=0.641$

c. $R$ squared $=0.789$ (Adjusted $R$ squared $=0.775$ 
Table (2). Regression analysis of the area of skin ulcer and fin erosion proportional to fish body area versus feeding intensity ( $F 1)$; coefficient of body condition (K); hepato-somatic index (HIS) ovarian-somatic index (OSI) ang testicular-somatic index (TSI) of Tilapia zillii.

\begin{tabular}{|c|c|c|c|c|c|}
\hline Variables & $n$ & $R$ & $R^{2}$ & $F$ value & $P$ \\
\hline \multicolumn{6}{|c|}{ Male Tilapia zillii } \\
\hline \multicolumn{6}{|c|}{ Severe skin alcer area $>15 \%$} \\
\hline FI & 32 & -0.96 & 0.92 & 159.9 & $0.01^{*}$ \\
\hline K & 32 & -0.94 & 0.88 & 103.8 & $0.01 *$ \\
\hline HSI & 32 & -0.92 & 0.84 & 70.5 & $0.01^{*}$ \\
\hline TSI \$ & 25 & -0.09 & 0.01 & 0.11 & $0.75^{* *}$ \\
\hline \multicolumn{6}{|c|}{ Severe fin erosion area $>30 \%$} \\
\hline FI & 30 & -0.88 & 0.77 & 86.2 & $0.02 *$ \\
\hline $\mathrm{K}$ & 30 & -0.91 & 0.83 & 121.3 & $0.01^{*}$ \\
\hline HSI & 30 & -0.21 & 0.04 & 0.74 & $0.88^{* *}$ \\
\hline TSI $\$$ & 21 & $-Q, l_{1} L_{1}$ & 0,01 & 0.19 & $2.31 * *$ \\
\hline \multicolumn{6}{|c|}{ Fenale Tilapia zillii } \\
\hline \multicolumn{6}{|c|}{ Severe skin ulcer...$>15 \%$} \\
\hline FI & & -0.91 & 0.82 & 109.8 & $0.01^{*}$ \\
\hline $\mathrm{K}$ & & -0.95 & 0.90 & 144.9 & $0.01^{*}$ \\
\hline HIS & 37 & -0.92 & 0.85 & 82.3 & $0.01^{*}$ \\
\hline OSI $\$$ & $3 i$ & -0.93 & 0.86 & 97.0 & $0.01 *$ \\
\hline \multicolumn{6}{|c|}{ Severe fin erosion area $>30 \%$} \\
\hline FI & 35 & -0.89 & 0.79 & 81.9 & $0.01^{*}$ \\
\hline $\mathrm{K}$ & 35 & -0.92 & 0.85 & 143.2 & $0.01 *$ \\
\hline IISI & 35 & -0.20 & 0.04 & 0.69 & $0.79^{* *}$ \\
\hline OSI $\S$ & 28 & -0.94 & 0.88 & 175.8 & $0.01^{*}$ \\
\hline
\end{tabular}

* Significant regression

$*$ Insignificant regression

$\S$ Calculated only for adult fish to avoid the effect of sexual ieiaturity 


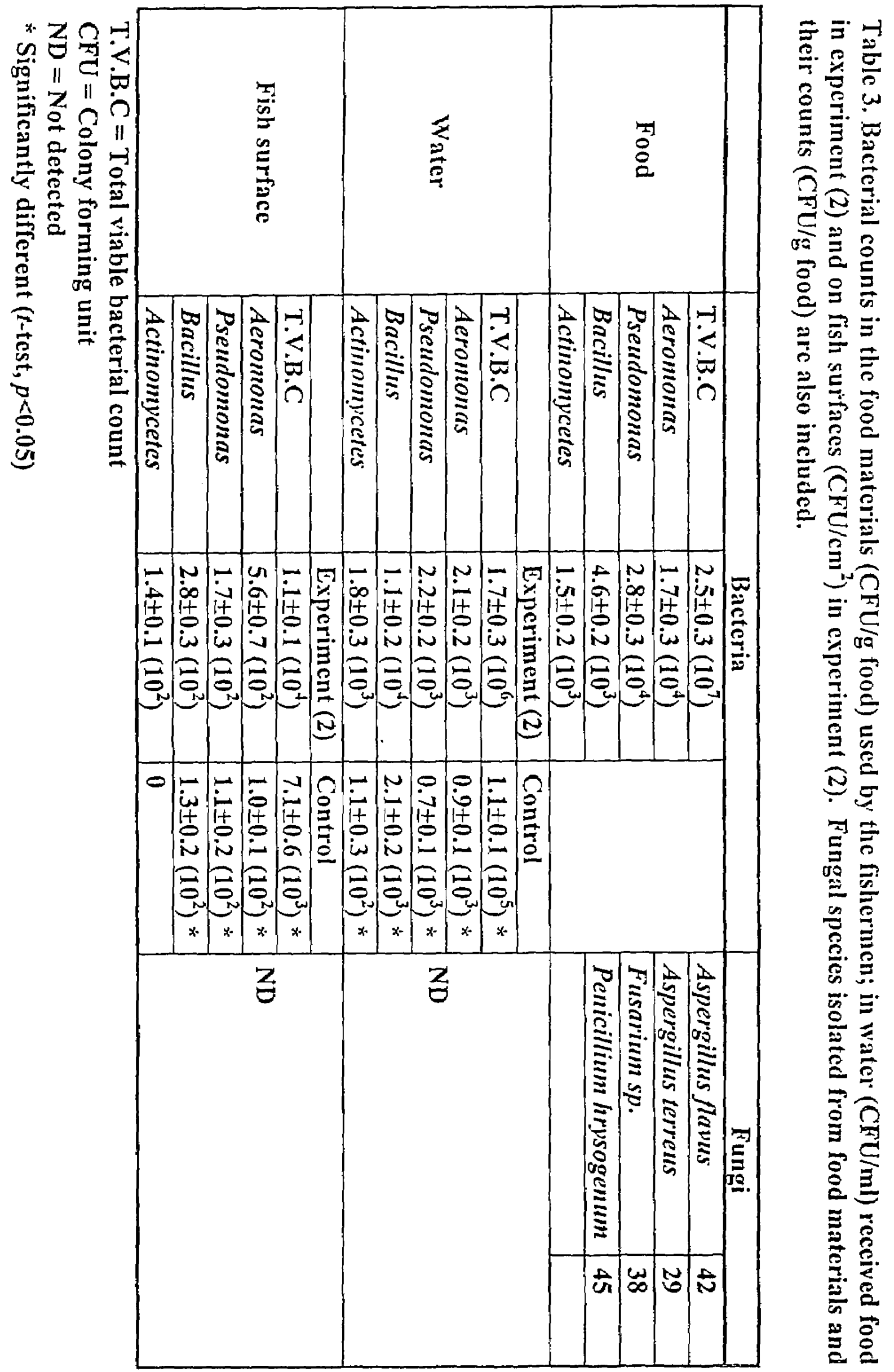


Fig. (2)

(a) Total lesions detected in $T$. zillii collected from different sites.

(b) Percentage of different lesions of $T$. zillii observed in each site.

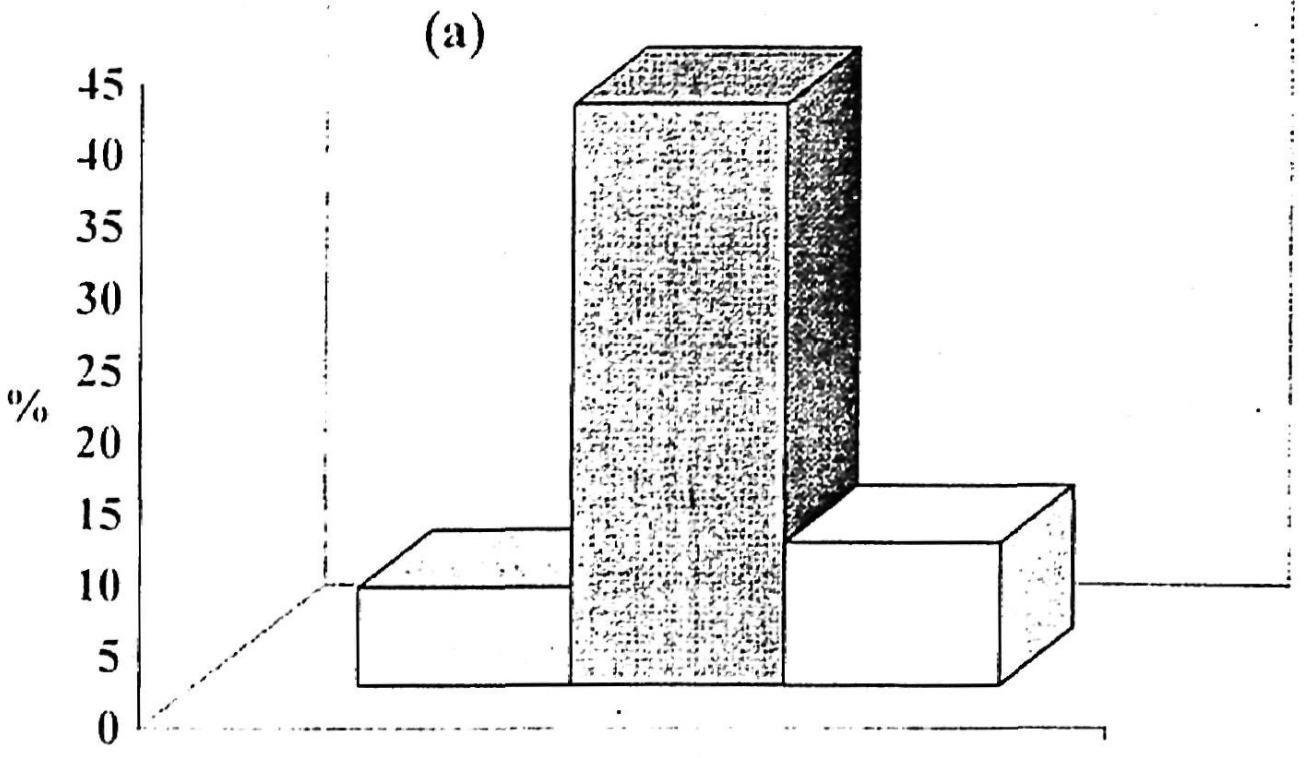

$\square$ Site A Site B

$\square$ Site C

Tôtal lesions

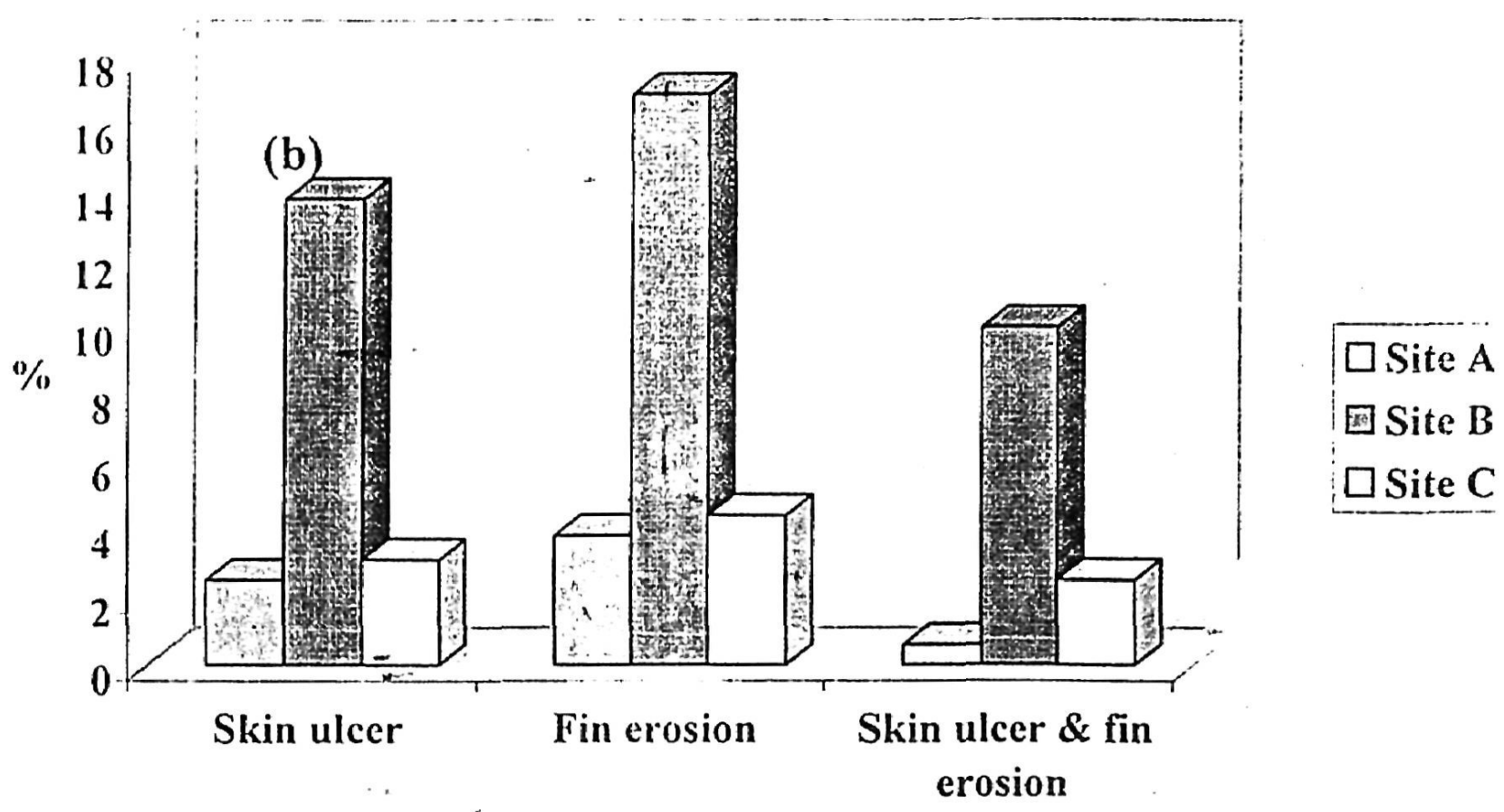


Fig. (3). (a) Percentage of different lesions detected in male and female Tilapia zillii collected from site B.

(b) Percentage of skin ulcers represented as ratios of body surface area of male and female Tilapia zillii captured from site $B$.

(c) Percentage of fin erosions represented as ratios of body surface area of male and female Tilapia zillii collected from site $B$.
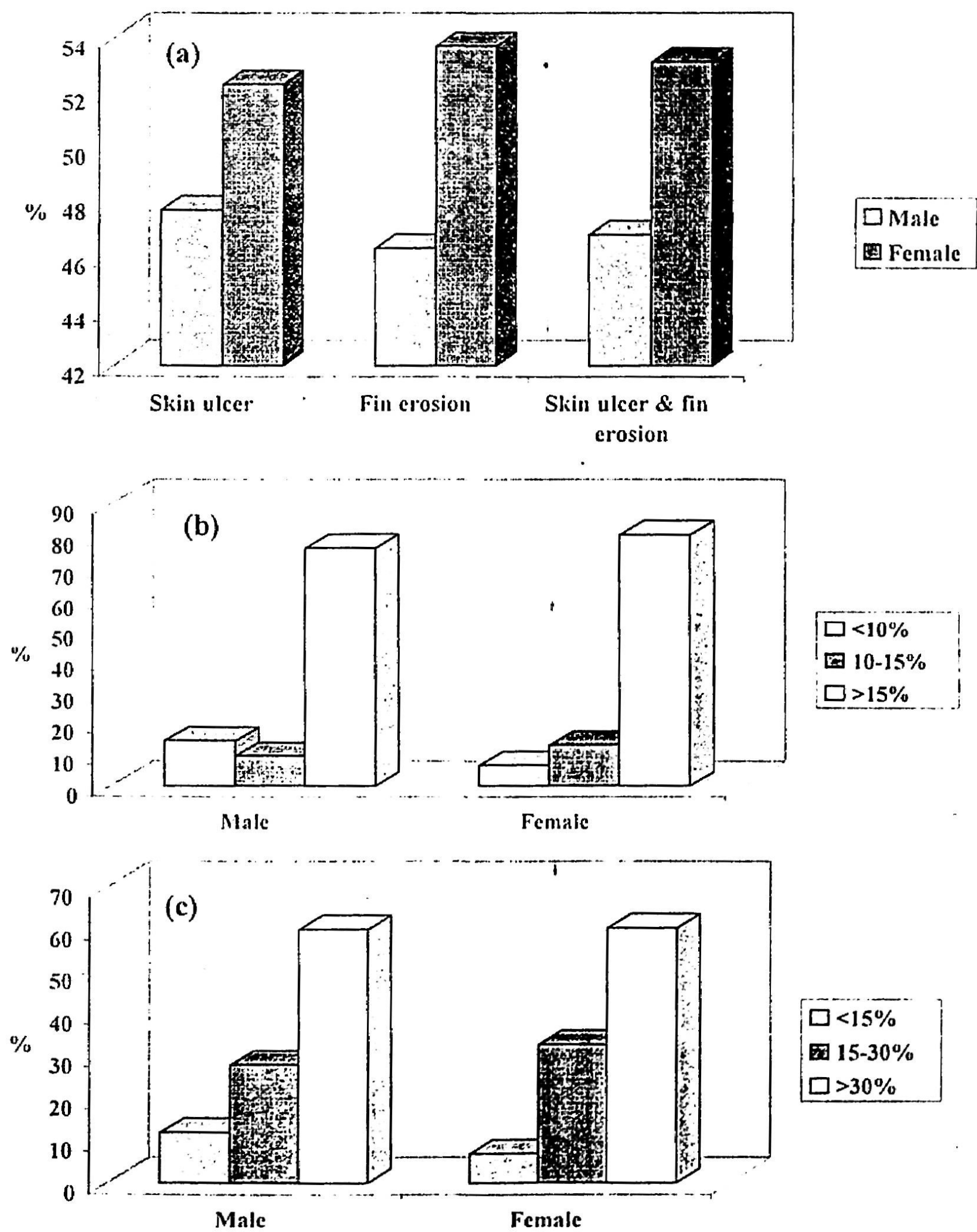

Female 


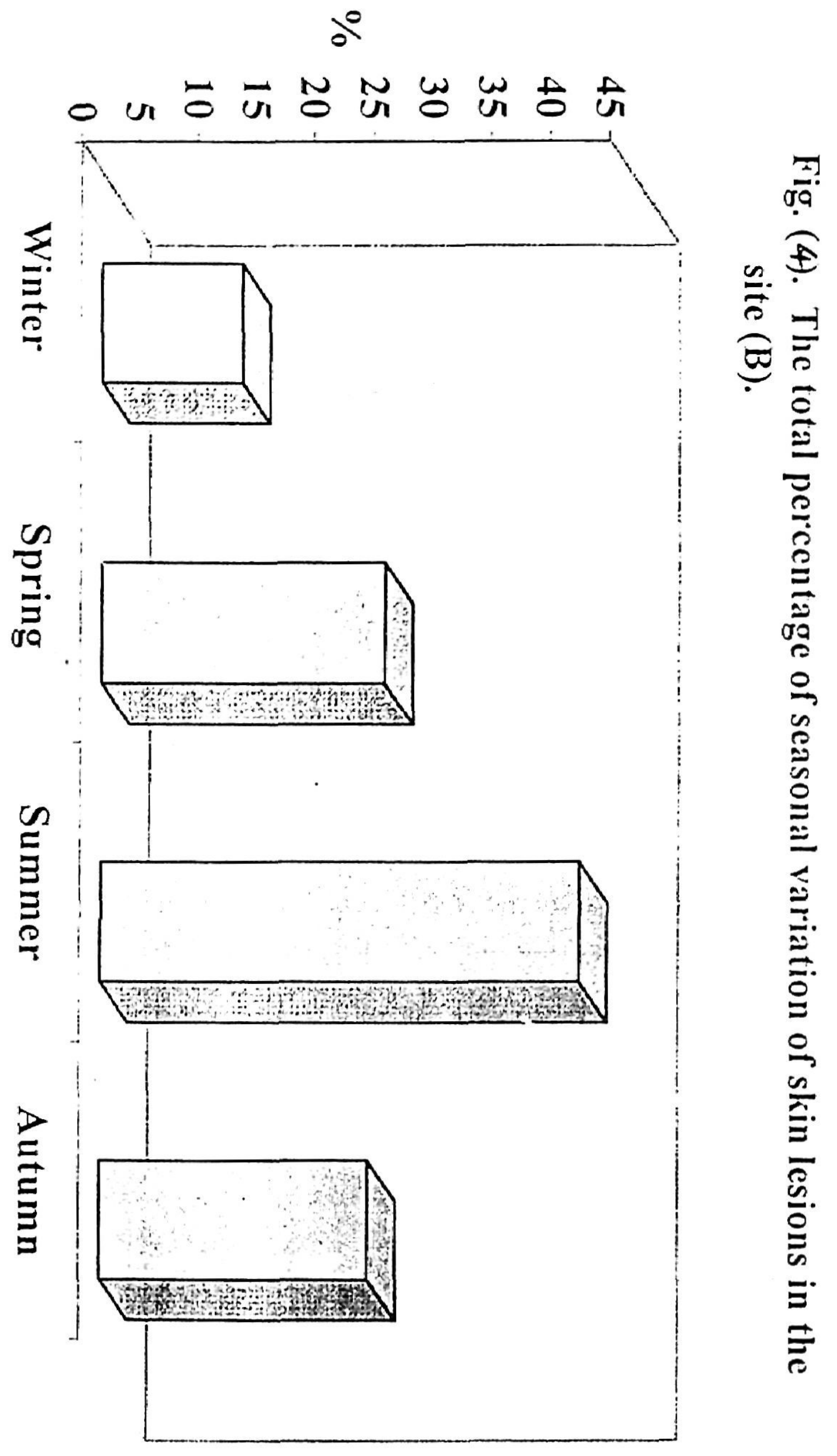




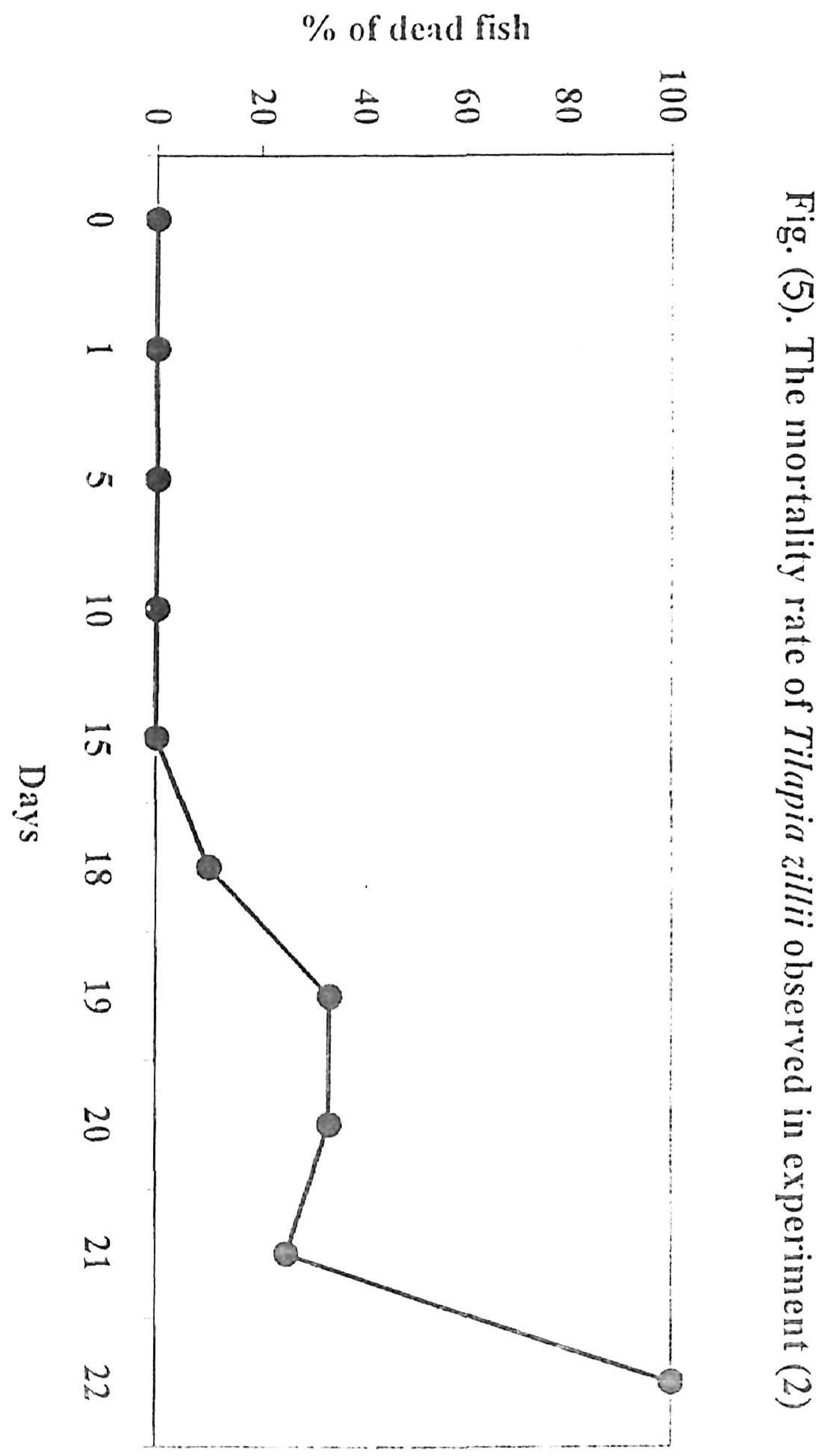



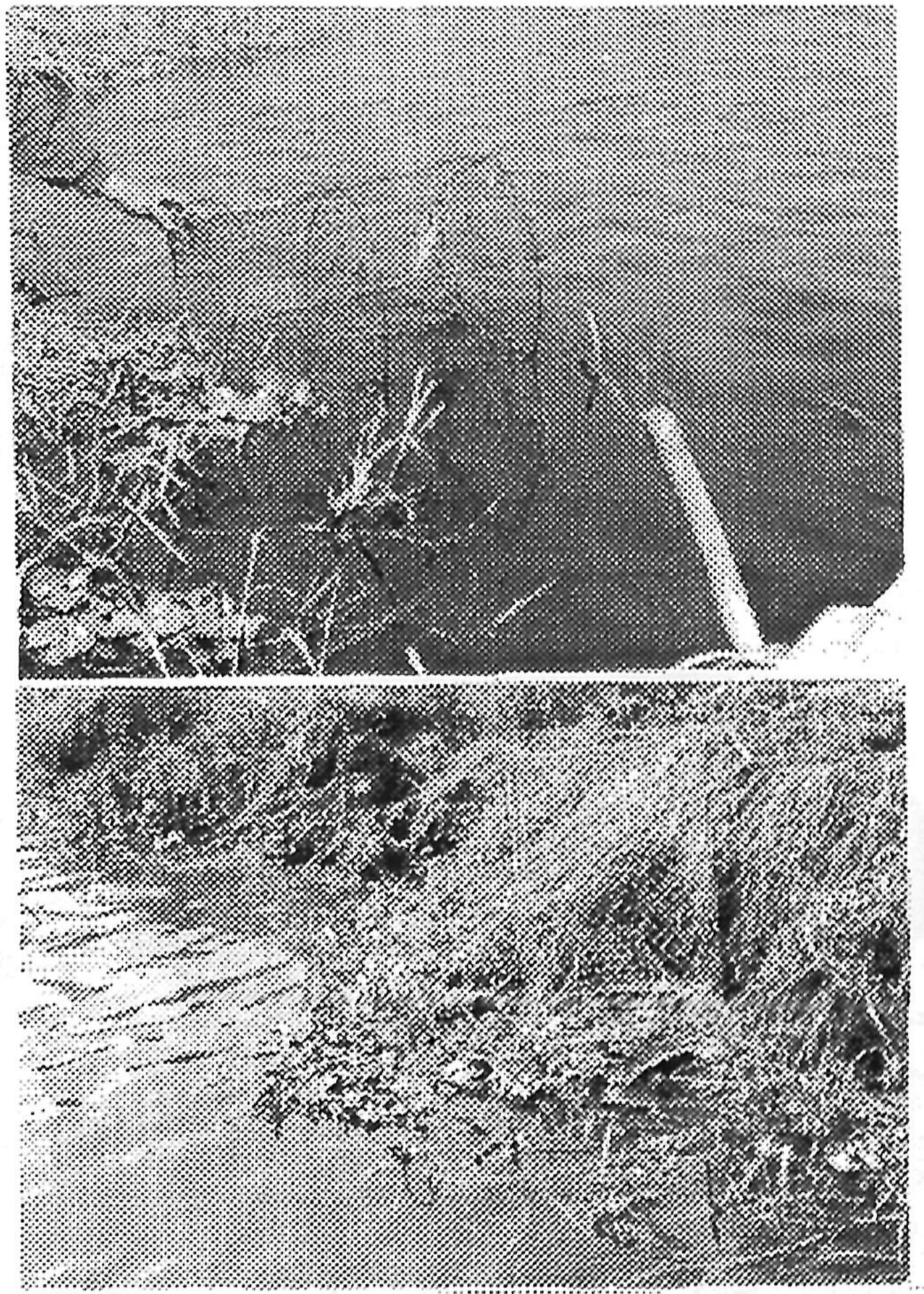

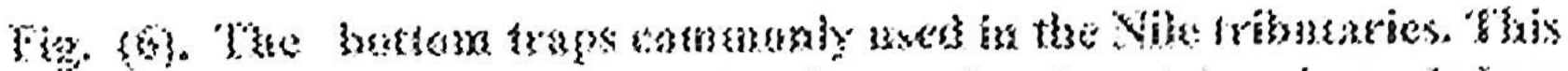
ty

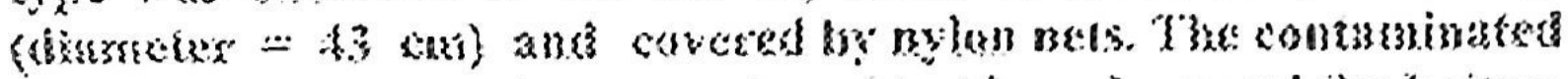

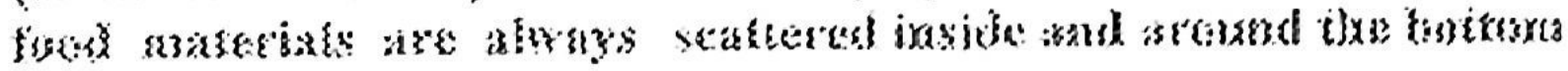
\{xispos. 

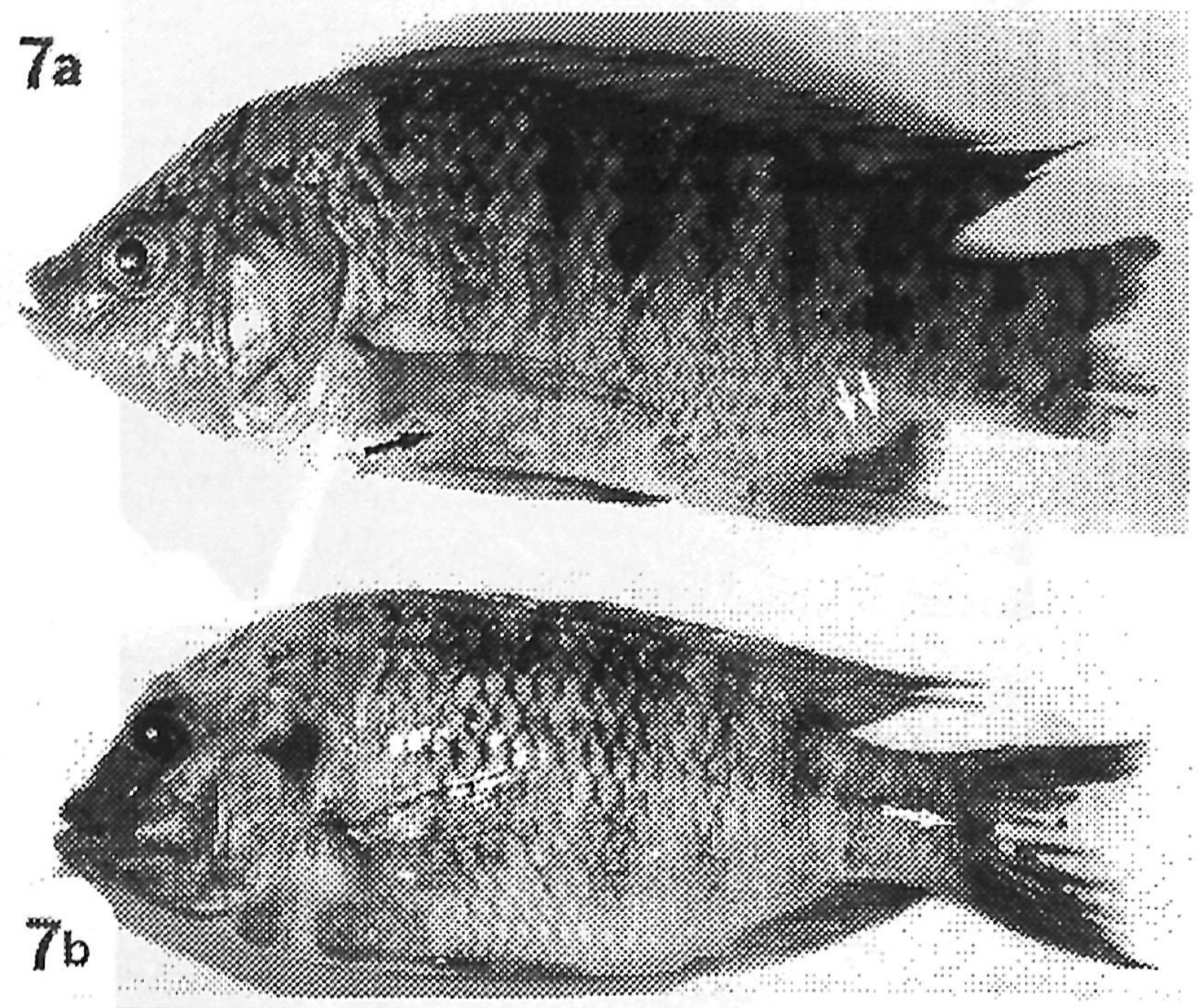

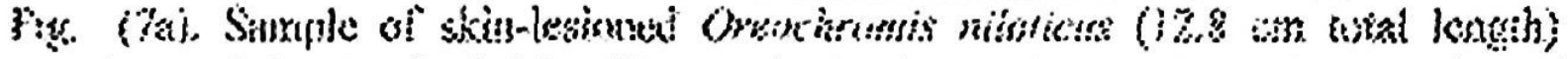

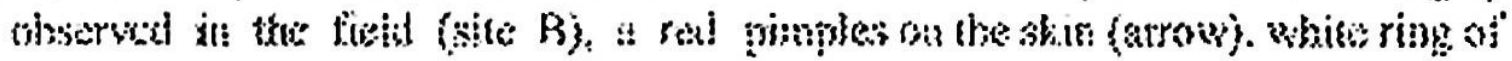

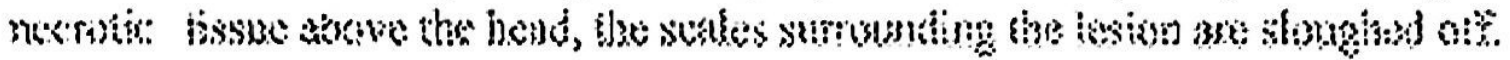

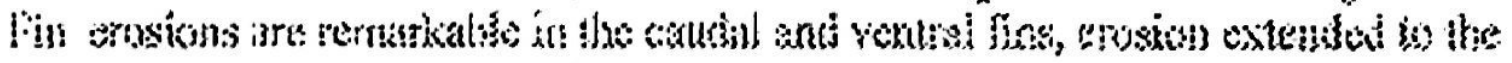

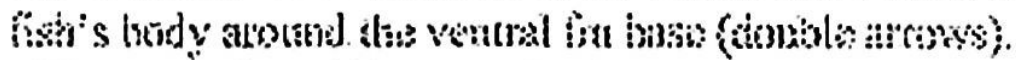

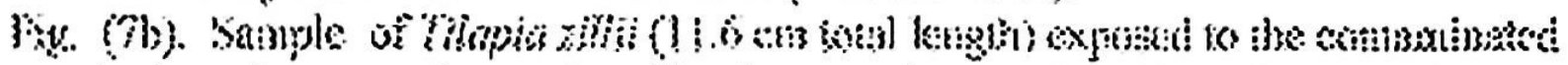

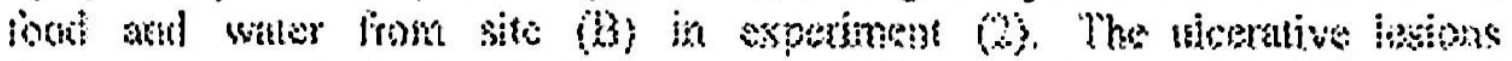

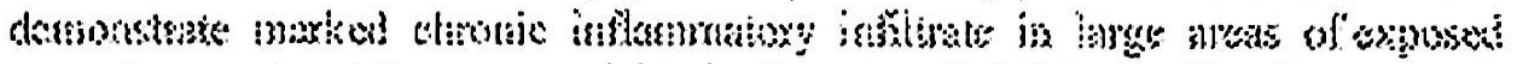

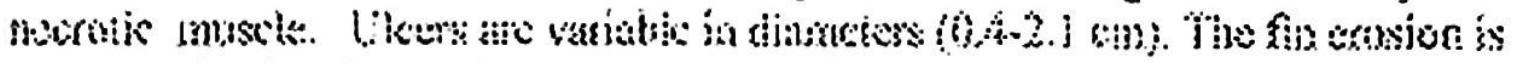

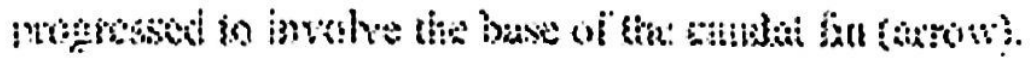

